University for Business and Technology in Kosovo

UBT Knowledge Center

UBT International Conference

2017 UBT International Conference

Oct 29th, 5:00 PM - 5:15 PM

\title{
The Impact of Television Debates in Persuasion
}

\author{
Kaltrina Ajeti \\ University for Business and Technology, kaltrina.ajeti@ubt-uni.net
}

Follow this and additional works at: https://knowledgecenter.ubt-uni.net/conference

Part of the Journalism Studies Commons

\section{Recommended Citation}

Ajeti, Kaltrina, "The Impact of Television Debates in Persuasion" (2017). UBT International Conference.

204.

https://knowledgecenter.ubt-uni.net/conference/2017/all-events/204

This Event is brought to you for free and open access by the Publication and Journals at UBT Knowledge Center. It has been accepted for inclusion in UBT International Conference by an authorized administrator of UBT Knowledge Center. For more information, please contact knowledge.center@ubt-uni.net. 


\title{
The impact of television debates in persuasion
}

\author{
Kaltrina Ajeti \\ UBT - Higher Education Institution, Lagjja KALABRIA p.n.10000 \\ Prishtina, Kosovo \\ kaltrina.ajeti@ubt-uni.net
}

\begin{abstract}
The media have a significant impact on the process of changing attitudes (Persuasion). Persuasive media forms are numerous and each of them is intended to provide audience attention, to get confidence, stimulate wish for the object, and motivate the audience to act. It is on the basis of these factors, that this research was also devised, which measures the impact of political television debates on the audience of Kosovo. The first phase of the research includes the identification and monitoring of the most-watched political debates on the most influential televisions in Kosovo such as: RTK1, KTV, RTV21 and Klan Kosova. The second phase involves the survey of 100 respondents of different ages and places, thus ensuring diversity in age and residence. Data collection and analysis is done through the Statistical Package for Social Sciences (SPSS). The outcomes did not support the first hypothesis that 'TV debates will affect persuasion for all ages and both genders', while in measuring two other hypotheses the results are significant, so we can conclude that' Moderators and guests are not credible, therefore, television debates do not affect persuasion 'and' Television debates affect the change of impression but not persuasion '.
\end{abstract}

Keywords: media, attitudes, persuasion, debates, moderator.

\section{INTRODUCTION}

As a result of communication, persuasion has its forms of influence, which begin from personal communication to mass communication. If we consider the recent years known as years of technology, we can say that the influence of mass media is irreplaceable and so far leads the list of persuasive forms.Persuasion is not the exclusive form of mass communication field, persuasion is first a social process that depends on psychic processes and then manifests itself with behavioral changes. So, we have a multi-dimensional process that has not emerged with the development of technology but has been most influenced in this period.Long time ago,as early as 2000 years agoit was writtenfor persuasion, Plato and Aristotle cited the persuasive techniques, their articles were collected by author Douglas Walton in the book "Dialectics, Persuasion and Rhetoric" (2007). The difference is that the goals and the persuasive tools have evolved and changed today.Forms and persuasive tools were created depending on the periods and political, economic and social impacts of the time. So in this chaotic environment of attempts to change the mass attitudes, a sophisticated media tool for the direction and transformation of attitudes, known as the 'meditic agenda', was created.Jennings Bryant and DolfZillmann in their book 'Media Effects' stressed that 'Media Agendas create issues and give direction to our attitudes to that issue'. This shows the undisputable 
role of the media in persuasion.In democratic societies one of the most effective media persuasive forms are television political debates. Naomi Comski in his article on 'Common Benefits' (Odonion Press, 1998), Comski stressed, "Debates are confined within a range of limitations that discuss issues within a limited amount of thoughts and ideas. While debate gives the impression that it can be discussed for all issues, very often, wider and deeper issues are not discussed, losing the important context.Although this often occurs by ignorance or non-professionalism, it is often systematic in nature. The smartest way to keep people passive and persuasive means never to limit the spectrum of thoughts, but vice versa, to allow powerful debate in that spectrum, to encourage them to express more critical and dissident views.Political debates include political rhetoric whether used by politicians, government officials, lobbyists, or activists. The rhetoric that remains the most used tool in television debates is considered an inseparable part of persuasion. O'Keefe stressed that "Persuasion has remained one of the greatest mysteries of rhetoric and disciplines similar to it." ${ }^{117}$. The rhetoric continues to be very difficult to analyze, not only because it comprises more emotional issues, but because we are more likely to see it in pieces and fragments, often filtered or edited by others. (Kennedy 1963; Tindale 1999; Jacobs 2000). One of the first studies aimed at measuring the influence of the media on attitudes has been the study of the impact of the appearance of violent scenes on television.With this study, the impact of media on people's attitudes and behaviors was first noted. ${ }^{118}$ (Gerbner, Gross, Signorielli, Morgan \& Jackson-Beeck, 1979; Morgan, 1983). On the other hand, there has been and continues to be scepticsthat opose the attribution of media influence on changing attitudes.Among them are the so-called 'traditional journalists' who insist that the media are to inform the public rather than change their attitudes. These statements have also supported some of the studies made in the last 20 years, where their findings have shown that mass media information influences the audience but does not necessarily affect changing of attitudes. ${ }^{119}$ This work has been built on these studies and theories, wanting to understand the causeeffect relationship between the media and the persuasion. How much impact do media have in persuasion? Are political television debates an adequate persuasive form? What factors should we take into account in measuring this complex psycho-social process?! Based on these research questions, three hypotheses of this research have been raised:

1. "Political television debates will influence persuasion to all ages and to both genders"

2. "Moderators and guests are not credible so they do not influence persuasion"

3. "Political debates influence the change of impression but not the persuasion"

\section{Methodology}

Given that attitudes are a complicated social process, the choice of methodology has been done with special care. The research is done in two parts. The first part of the research included monitoring the most watched television debates in Kosovo, giving particular importance to moderators, the topic being discussed and guests being invited to these debates. The monitoring period has eliminated the

${ }^{117} \mathrm{O}$ 'Keefe, D. J. (2002).Persuasion: Theory and research, 2nd edn; pg. 575 ; Thousand Oaks, CA: Sage;

118 Bryant J \&Zillmann D.(2002) Media Effects - Advanced in theory and research, 2nd edn; pg.45-46 ; Lawrence Erlbaum Associates, Inc. Mahwah, New Jersey

3. McCombs, M., \& Reynolds, A. (2002). News Influence on Our Pictures of the World. 
election campaign period, because in this period all the candidates that competed in the election process, were involved in television debates, editors themselves also were more careful due to the strict monitoring of the media monitoring mechanisms during this period.The second part involves measuring audience attitudes, a measure which is achieved through the quantitative method, the survey method. Demographic data includes age, gender, place of residence and educational level. These variables determine the raised hypotheses in this research. In the survey, 100 respondents participated, of whom $48 \%$ were females and $44 \%$ male. Despite the solid number of participants, great importance has been paid to the diversity of the participants in the age, level of education and residence.

The vast majority of participants have completed university studies, while $20 \%$ of them have completed high school and only $7 \%$ of them have low education. This variable is measured in order to identify whether the level of education affects the audience's level of persuasiveness. Participants are chosen by using random method.The target group has included the age of 20 to 60 years. In the first age group we have $59.0 \%$ of the participants, including the age from 20 to 40 , while $39 \%$ belong to the second age group, which includes the age from 41-60. The target group has eliminated young people under the age of 20 as it is considered that young people under the age of 20 have poorly established attitudes regarding the dimensions studied in this research.

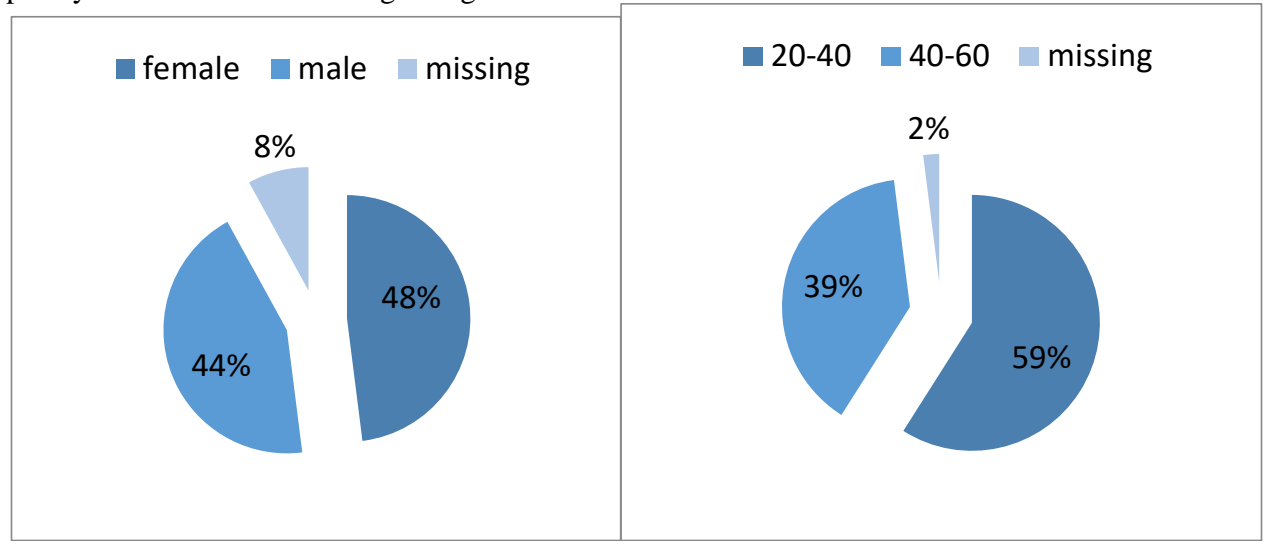

The majority of the questionnaire was applied in Pristina where $70 \%$ of participants are residents of the capital, while another part of the questionnaire was applied in the town of Podujevo, where $10 \%$ of the participants come from this city. The lowest percentage is from the cities of Peja, Gjakova and Gjilan $2 \%$ for each one and from the rural areas of which we have $1 \%$ of the participants. 


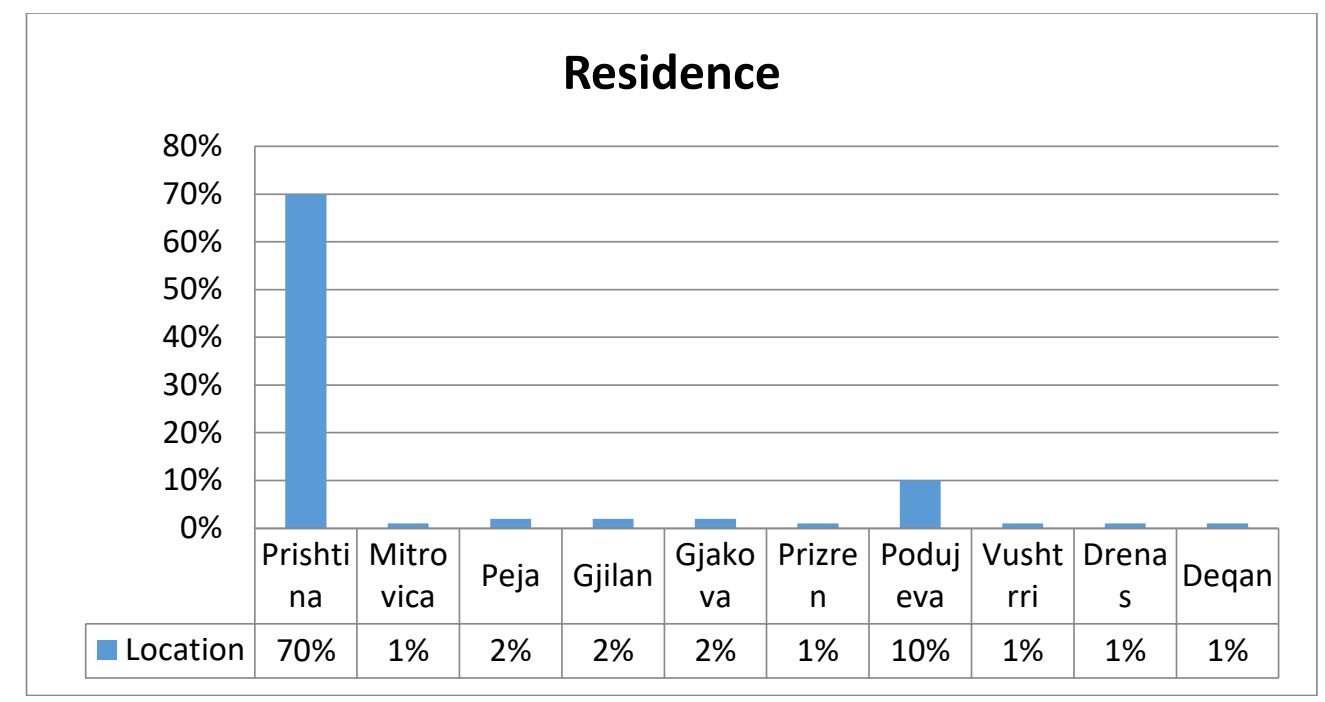

The vast majority of participants have completed university studies, while $20 \%$ of them have completed high school and only $7 \%$ of them have primary education. This variable is measured in order to identify whether the level of education affects the audience's level of persuasiveness. Participants are chosen by using random method.

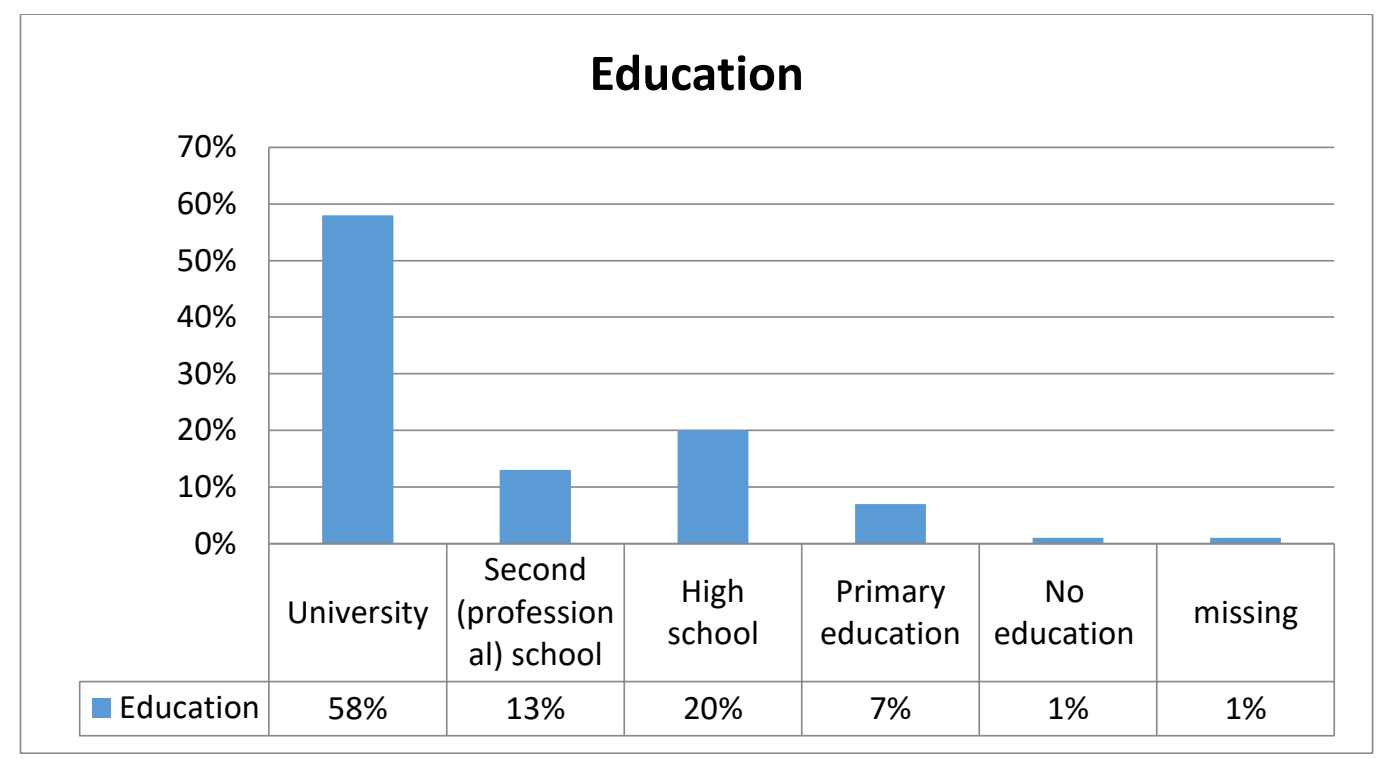

Likert's scale was use in the questionnaire, where the interest of participants in TV debates in Kosovo media was measured through 20 questions, their opinions on moderators, topics and guests 
invited to these debates and their political attitudes whether they have changed their attitudes or not, influenced by these TV debates.

\section{RESULTS}

Respondents' attitudes are measured through the Likert's scale, where affirmative scale 1 indicates lack of compliance whereas scale 4 indicates the highest level of compliance. Since there are also 3 neutral points- I partially disagree and 4 - I fully agree then it is necessary to extract the average in order to see how the attitudes of the participants vary.

\section{Absolutly do not agree}

The data

\section{I partially disagree}

\section{I partially agree}

\section{I fully agree}

analysis was done through the statistical package for social science (SPSS), through which the average and standard deviation was derived, where the highest rate was 80 and the following results were obtained $X=52.1$ and DS $=6.41$. In the second phase of data analysis, participants were divided into two groups according to age and gender, in order to measure the first hypothesis of this research. Thedata analysis was done through the T-test and significance in the gender ratio is Sig = 0.397 which means that the results were insignificant. Then the sample was split according to the age ratio and the results again emerged not significant with $\mathrm{Sig}=0.73$. Expectations for the impact of television debates have been large. According to the initial hypothesis it is expected that television debates would influence the persuasion. However, the results showed no significance in either of the measurements either by gender or by age-sharing. Therefore, in the second section of the data analysis, special dimensions were considered regarding this group that relate to the moderators and guests of these TV debates. 


\begin{tabular}{|l|l|l|l|l|}
\hline & $\begin{array}{l}\text { Absolutlydo } \\
\text { not agree }\end{array}$ & $\begin{array}{l}\text { Partly do } \\
\text { not agree }\end{array}$ & $\begin{array}{l}\text { Partly } \\
\text { agree }\end{array}$ & $\begin{array}{l}\text { Fully } \\
\text { agree }\end{array}$ \\
\hline $\begin{array}{l}\text { 1. Television debates are led by } \\
\text { professional and credible people }\end{array}$ & $24 \%$ & $37 \%$ & $29 \%$ & $7 \%$ \\
\hline $\begin{array}{l}\text { 2. Topics in TV debates are always } \\
\text { selected and actual }\end{array}$ & $21 \%$ & $30 \%$ & $36 \%$ & $5 \%$ \\
\hline $\begin{array}{l}\text { 3., Adequate guests are always invited } \\
\text { in the TV debate }\end{array}$ & $26 \%$ & $32 \%$ & $29 \%$ & $5 \%$ \\
\hline $\begin{array}{l}\text { 4. The are mainly political topics in } \\
\text { political debates }\end{array}$ & $3 \%$ & $13 \%$ & $35 \%$ & $40 \%$ \\
\hline $\begin{array}{l}\text { 5. In political TV debates, we notice } \\
\text { political partiality made by moderators } \\
\text { depending on the medium }\end{array}$ & $5 \%$ & $15 \%$ & $30 \%$ & $39 \%$ \\
\hline $\begin{array}{l}\text { 6. I have managed to create an attitude } \\
\text { from a show or cycle of shows on an } \\
\text { issue }\end{array}$ & $12 \%$ & $19 \%$ & $43 \%$ & $15 \%$ \\
\hline $\begin{array}{l}\text { 7. I have managed to change my } \\
\text { attitude from a show or cicle of shows } \\
\text { for an issue. }\end{array}$ & $10 \%$ & $30 \%$ & $34 \%$ & $14 \%$ \\
\hline $\begin{array}{l}\text { 8. From political debates I have made } \\
\text { up my sympathy for a political party or } \\
\text { a public person }\end{array}$ & $26 \%$ & $18 \%$ & $29 \%$ & $15 \%$ \\
\hline $\begin{array}{l}\text { 9. From political debates I have } \\
\text { changed the attitude for a political party } \\
\text { or for } \\
\text { a public person }\end{array}$ & $27 \%$ & $22 \%$ & $24 \%$ & $16 \%$ \\
\hline $\begin{array}{l}\text { 10. Political debates are very } \\
\text { monotonous and I do not watch them. }\end{array}$ & $15 \%$ & $30 \%$ & $18 \%$ & $21 \%$ \\
\hline $\begin{array}{l}\text { 11. TV debates can not change my } \\
\text { political attitudes }\end{array}$ & $14 \%$ & $16 \%$ & $40 \%$ \\
\hline $\begin{array}{l}\text { 12. I have changed my political stand } \\
\text { during these post-war years }\end{array}$ & $36 \%$ & $11 \%$ & $14 \%$ & $23 \%$ \\
\hline $\begin{array}{l}\text { 13. I have changed my political attitude } \\
\text { because my family has also changed its } \\
\text { attitude }\end{array}$ & $67 \%$ & $5 \%$ & $6 \%$ \\
\hline
\end{tabular}

At this stage of analysis, all important dimensions of television debates and their impact on persuasion are measured. According to the results, TV debates mainly cover political issues where 
$40 \%$ of participants responded with the affirmative answer "Fully Agree". On the other hand, the interest in these political TV debates has been large and thus it rejected the conclusion that political debates are monotonous and that the participants did not follow them. It means that political television debates manage to raise public attention, but what are other factors that have influenced the audience not to be persuaded, despite frequent exposure.According to the results we have seen that respondents have given negative answers and have not considered both the broadcast moderators and the invited guests as credible. Asked whether "TV debates are run by professional and credible people", $37 \%$ of respondents answered negatively the question "Partly disagree" in spite of the reply 'fully agree', which reply was $7 \%$, this is probably the consequence of the next question if 'In these TV debates we notice the moderator political partiality depending on the media' where $39 \%$ of the respondents replied with 'Fully Agree'.Relatively similar answers were also given to the question of credibility and reliability of guests, where $32 \%$ of respondents again responded with the negative answer "I partly disagree ", despite the topics discussed in these debates they were considered adequate by $36 \%$ of the respondents. On the other hand, the measurements produced interesting results. When asked whether respondents had created or changed their position on a particular issue debated in TV, the responses were positive, $43 \%$ of the respondents stated that they had established positions, while $34 \%$ of them admitted that they had changed their attitude, which means that the televisions debates have influenced persuasion with regard to certain social issues.But the opposite was in the case of a stand against political parties or a public person. In the first question whether they "had got any sympathy for a political party or a public person," $29 \%$ responded positively, whereas in the very close question but which introduces the dimension attitudes, whether they had changed their attitudes against one political subject or public person from these political debates, $27 \%$ of them responded negatively "Absolutely disagree". While in the subsequent finding, which was a direct statement, "Political debates could not change my political stance", $40 \%$ of respondents stated "Fully Agree". In the final questions, if respondents had changed their political attitude during the post-war years, $36 \%$ of them responded negatively "Absolutely disagree" but a large percentage that should be taken into account $23 \%$ of them gave the affirmative answer "Fully agree"; Whereas the categorically negative answers to the question "I have changed the political attitude because my family has also changed it "were given by the largest number of respondents, the percentage of negative responses "Absolutely disagree" was $60 \%$ which is the largest percentage given in this questionnaire. Preliminary results that emerged in the first phase of the research prove the lack of persuasion from television debates. But their separate analysis have given interesting results especially in final questions related to their attitudes and changes of these attitudes in report with the issues, public persons and political parties. Therefore, the next phase of data analysis divided the sample according to sex, age, place of residence and educational level in the last 5 issues. 
The results were the following:

\begin{tabular}{|c|c|c|c|c|c|c|c|}
\hline Question & Answer & $\mathbf{F}$ & $\mathbf{M}$ & $20-40$ & $\begin{array}{l}41- \\
60\end{array}$ & Residence & Education \\
\hline $\begin{array}{l}39 . \quad \text { I have } \\
\text { formed my } \\
\text { attitude from a } \\
\text { TV debate or a } \\
\text { cicle of debates } \\
\text { for an issue. }\end{array}$ & $\begin{array}{l}\text { I partly } \\
\text { agree } \\
43 \%\end{array}$ & $\begin{array}{l}23 \\
\%\end{array}$ & $\begin{array}{l}2 \\
0 \\
\%\end{array}$ & $25 \%$ & $\begin{array}{l}21 \\
\%\end{array}$ & $\begin{array}{c}\text { Prishtinë } 35 \\
\% \\
\text { Podujevë } 8 \\
\% \\
\text { Gjilan } 1 \% \\
\text { Gjakovë 1\% } \\
\text { Vushtrri 1\% }\end{array}$ & $\begin{array}{c}\text { University } 31 \\
\% \\
\text { High Sch. } 2 \% \\
\text { Secon. school } \\
12 \%\end{array}$ \\
\hline $\begin{array}{l}40 . \quad \text { I have } \\
\text { managed to } \\
\text { change } \\
\text { attitude from } \mathrm{TV} \\
\text { debate of from a } \\
\text { cicle of } \mathrm{TV} \\
\text { debates for and } \\
\text { issue }\end{array}$ & $\begin{array}{c}\text { Partlyi } \\
\text { agree } \\
34 \%\end{array}$ & $\begin{array}{l}20 \\
\%\end{array}$ & $\begin{array}{c}1 \\
0 \\
\%\end{array}$ & $23 \%$ & $\begin{array}{l}10 \\
\%\end{array}$ & $\begin{array}{c}\text { Prishtinë } 28 \\
\% \\
\text { Podujevë } 5 \\
\% \\
\text { Prizren } 1 \% \\
\text { Mitrovicë } 1 \\
\% \\
\text { Vushtrri } 1 \%\end{array}$ & $\begin{array}{c}\text { University } 25 \\
\% \\
\text { High School1 } \\
\% \\
\text { Secon. school } \\
9 \%\end{array}$ \\
\hline $\begin{array}{l}\text { 41. From TV } \\
\text { debates I have } \\
\text { created a } \\
\text { sympathy for a } \\
\text { political party or } \\
\text { a public person }\end{array}$ & $\begin{array}{l}\text { Partly } \\
\text { agree } \\
29 \%\end{array}$ & $\begin{array}{l}14 \\
\%\end{array}$ & $\begin{array}{l}1 \\
5 \\
\%\end{array}$ & $18 \%$ & $\begin{array}{l}14 \\
\%\end{array}$ & $\begin{array}{c}\text { Prishtinë } 22 \\
\% \\
\text { Podujevë } 5 \\
\% \\
\text { Gjilan } 2 \% \\
\text { Mitrovicë } \\
1 \% \\
\text { Gjakovë } 1 \% \\
\text { Vushtrri } 1 \%\end{array}$ & $\begin{array}{c}\text { University } 24 \\
\% \\
\text { Secon. school } \\
8 \%\end{array}$ \\
\hline $\begin{array}{l}\text { 42. By watching } \\
\text { political debates } \\
\text { I have changed } \\
\text { my attitude for a } \\
\text { political party or } \\
\text { a public person }\end{array}$ & $\begin{array}{l}\text { Absolutly } \\
\text { do not } \\
\text { agree } 27 \%\end{array}$ & $\begin{array}{l}10 \\
\%\end{array}$ & $\begin{array}{l}1 \\
7 \\
\%\end{array}$ & $17 \%$ & $\begin{array}{l}10 \\
\%\end{array}$ & $\begin{array}{c}\text { Prishtinë } 26 \\
\% \\
\text { Podujevë } 2 \\
\% \\
\text { Gjilan } 1 \%\end{array}$ & $\begin{array}{c}\text { University } 20 \\
\% \\
\text { High School } 2 \\
\% \\
\text { Secon. school } \\
7 \%\end{array}$ \\
\hline 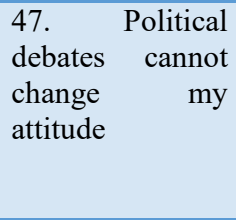 & $\begin{array}{c}\text { Fully agree } \\
40 \%\end{array}$ & $\begin{array}{l}20 \\
\%\end{array}$ & $\begin{array}{l}2 \\
0 \\
\%\end{array}$ & $25 \%$ & $\begin{array}{l}17 \\
\%\end{array}$ & $\begin{array}{c}\text { Prishtinë } 34 \\
\% \\
\text { Podujevë } 7 \\
\% \\
\text { Gjilan } 1 \% \\
\text { Gjakovë } 1 \%\end{array}$ & $\begin{array}{c}\text { University } 29 \\
\% \\
\text { High School } 5 \\
\% \\
\text { Second. school } \\
5 \%\end{array}$ \\
\hline $\begin{array}{lr}49 . \quad \text { I have } \\
\text { changed my } \\
\text { political stand } \\
\text { during the post- } \\
\text { war years }\end{array}$ & $\begin{array}{c}\text { Absolutly } \\
\text { do not } \\
\text { agree } \\
36 \%\end{array}$ & $\begin{array}{l}17 \\
\%\end{array}$ & $\begin{array}{c}1 \\
9 \\
\%\end{array}$ & $18 \%$ & $\begin{array}{l}19 \\
\%\end{array}$ & $\begin{array}{c}\text { Prishtinë } 30 \\
\% \\
\text { Podujevë } 6 \% \\
\text { Gjakovë } 1 \% \\
\text { Drenas } 1 \% \\
\text { Deqan } 1 \%\end{array}$ & $\begin{array}{c}\text { University } 20 \\
\% \\
\text { High School } 4 \\
\% \\
\text { Second. school } \\
2 \% \\
\text { Prim. School } 1 \\
\%\end{array}$ \\
\hline
\end{tabular}




\begin{tabular}{|c|c|c|c|c|c|c|c|}
\hline & & & & & & & No educ. $1 \%$ \\
\hline $\begin{array}{lr}\begin{array}{l}50 . \\
\text { changed }\end{array} & \text { have } \\
\text { political stand } \\
\text { because } \\
\text { family has } \\
\text { changed it }\end{array}$ & $\begin{array}{c}\text { Absolutly } \\
\text { donot agree } \\
67 \%\end{array}$ & $\begin{array}{l}40 \\
\%\end{array}$ & $\begin{array}{l}2 \\
7 \\
\%\end{array}$ & $47 \%$ & $\begin{array}{l}24 \\
\%\end{array}$ & $\begin{array}{c}\text { Prishtinë } 63 \\
\% \\
\text { Podujevë } 6 \\
\% \\
\text { Prizren } 2 \% \\
\text { Gjakovë } 1 \% \\
\text { Drenas } 1 \%\end{array}$ & $\begin{array}{c}\text { University } 52 \\
\% \\
\text { High School } 6 \\
\% \\
\text { Second. school } \\
13 \% \\
\text { Prim. School } 1 \\
\%\end{array}$ \\
\hline
\end{tabular}

The gender, age and level of education is to a considerable extent balanced and therefore gives us comparable results, however, despite the attempt to have as many as possible respondents from various regions of Kosovo, the large number of respondents results to be from Prishtina, which makes this category a bit unmatched. However, despite the small percentage of respondents from other centers if we look at the questions one by one, we will notice differences. Here we can see the difference:In the statement 'From political debates I have changed my attitude for a political party or a public person' in the last two affirmative questions the responds were mostly given by female participants, whereas in regard of age respondents from 20-40 years were the most persuasive in the process. In regard of towns only Pristina, Podujeva, Prizren and Gjilan had given positive responds against other towns.In the statement "I changed my political stand during the postwar years" it turned out that: Women and ages from 20-40 had a higher percentage of affirmative responses, $22 \%$ of respondents in Pristina claimed to have changed their political stand, $1 \%$ in Podujevo, $1 \%$ inGjilan and $1 \%$ in Gjakova. Whereas in Drenas, Deçan and Vushtrri the responses were negative, at the same time they are compatible with the results of all elections held in Kosovo in which in these municipalities, especially the first two in all elections held ,the same political subject got the majority of mandates. Regarding the level of education only respondents with university studies showed fluctuations but were not very significant despite negative responses. While in the last finding that "I have changed attitudes because my family has changed attitude" the affirmative responses were numerically very low despite the negative answers and mainly they were from regions which had positively answered the preliminary question, that is, Pristina, Podujeva, Gjilan and Gjakova.

\section{Conslusions}

Despite the large number of political television debates in Kosovo and the great interest of the audience to follow these debates, the results showed that television debates do not influence the change of political attitude among Kosovo's citizens. The initial hypothesis that 'Political television debates will influence persuasion of all ages and both genders' was not supported by statistical results, through other measurements each phase of the persuasion process was analyzed in order to identify the factors that potentially affected the debates as a media persuasive formwhich didnotinfluence the Kosovo audience. Persuasive media forms are intended to provide audience attention, gain confidence, stimulate the wish for the object, and motivate the audience to act. From the results we emerged it emerges that: 
- Television debates in Kosovo media manage to provide the attention of the audience. This indicates that the first stage of persuasion has been successful because these political TV debates have managed to get the audience's attention in Kosovo, but this has not ensured the success of subsequent persuasive stages which means credibility.

- The non-credibility of moderators and guests influences the creation of mistrust of audiences. Credibility, physical similarity, message, message volume, emotion reasoning are some of the sources of change of attitudes that must be taken into account in the process of persuasion. In our measurements it turns out that this dimension has failed in the respect of credibility of moderators and guests. A large percentage of respondents stated that they consider moderators uncredible due to their partiality with the editorial policies of the media they belonged and questioned the credibility of the guests, mainly political persons. At this stage, the process of persuasion has failed, which also leds to the failure of the third element, motivation.

- Television debates influence the creation of opinion (like) of a public person or a political subject but do not motivate the audience to change their attitudes.

\section{References}

1. Ajzen, I. (1988). Attitudes, personality, and behavior.Chicago: Dorsey Press.

2. Berkowitz, L., Jaffee, S., Jo, E., \&Troccoli, B. (2000). Some conditions affecting overcorrectionof the judgment-distorting influence of one's feelings. In J. P. Forgas (Ed.), Feelingand thinking: The role of affect in social cognition. Cambridge: Cambridge University Press.

3. Bryan, J. \& Zillmann, D. (2002) Media Effects, Advances in Theory and Research, Mahwah,NJ: Lawrence erlbaum.

4. Brislin, Richard. Understanding Culture's Influence of Behavior, New York; Harcourt Brace Jovanovich, 1993.

5. Cialdini, Robert B. Influence: The Neë Psychology of Modern Persuasion. Neë York; Ëilliam Morroë, 1985 .

6. Dillard, J. P., \&Pfau, M. (eds.) (2002). The persuasion handbook: Developments in theory andpractice. Thousand Oaks, CA: Sage.

7. Dragoti, Edmond (2004), Social Psichology, stands and cange stands, page. 164-190

8. Fishbein, M., \&Ajzen, I. (1975). Belief, attitude, intention, and behavior: An introduction totheory and research. Reading, MA: Addison-Wesley.

9. Glynn, C. J., Herbst, S., O'Keefe, G. J., \& Shapiro, R. Y. (1999). Public opinion. Boulder, $\mathrm{CO}$ :

10. Westview Press.Hogan. K, (2004) The psychology of persuasion, Publisher : Pelican Publishing company,Inc.

11. Hornik, R. C. (ed.) (2002). Public health communication: Evidence for behavior change. Mahwah, NJ:Lawrence Erlbaum.

12. Kardes, F. R., Herr, P. M., \&Nantel, J. (eds.) (2005). Applying social cognition to consumer-focusedstrategy. Mahwah, NJ: Laërence Erlbaum.

13. Mills, W, (1951) White Collar: The American Middle Classes,pg. 182, 183, 187. Publisher: Oxford University Press. 
14. McQuail, D. (2000). Mass communication theory. Thousand Oaks, CA: Sage.

15. Mutz, D. C., Sniderman, P. M., \& Brody, R. A. (eds.) (1996). Political persuasion and attitude change.Ann Arbor: University of Michigan Press.

O'Keefe, D. J. (2002). Persuasion: Theory and research, 2nd edn. Thousand Oaks, CA: Sage.

16. Singhal, A., Cody, M. J., Rogers, E. M., \&Sabido, M. (eds.) (2004). Entertainmenteducation and social change: History, research, and practice. Mahëah, NJ: Lawrence Erlbaum.

17. Petty, R. E., \&Cacioppo, J. T. (1986a). Communication and persuasion: Central and peripheralroutes to attitude change. New York: Springer-Verlag.

18. Walton, Douglas. (2007) Media Argumentation, Dialectic Persiasion and Rethoric, Publisher : Cambridge University Press.

19. Wallack, L., Woodruff, K., Dorfman, L., \& Diaz, I. (1999).News for a change: An advocate's guide to working with the media. Thousand Oaks, CA: Sage. 